\title{
Differential responses of 15 cowpea genotypes to three Striga hot spots in Niger
}

\author{
M. SALIFOU ${ }^{1 *}$, J. B. L. S. TIGNEGRE ${ }^{2}$, P. TONGOONA ${ }^{3}$, S. OFFEI ${ }^{3}$, \\ K. OFORI ${ }^{3}$ and E. DANQUAH ${ }^{3}$

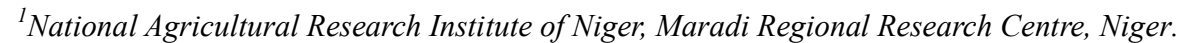 \\ ${ }^{2}$ The world Vegetable Centre, West and Central Africa Samanko research station, Bamako, Mali. \\ ${ }^{3}$ West Africa Centre for Crop Improvement, University of Ghana, Accra, Ghana. \\ *Corresponding author: E-mail: masalif2000@yahoo.fr; Tel: (+227) 9236 8468/89468874
}

\begin{abstract}
Striga gesnerioides (Wild.) Vatke is the main biotic factor restricting yield of cowpea in Sub-Saharan Africa (SSA) in general and particularly in Niger. To date, seven different races infesting cowpea have been identified in Africa based on differential responses of cowpea varieties. It was desirable to verify whether there are other Striga races a part from the race SG3 reported so far in Niger. Field and pots experiments were conducted during two years in order to identify the different Striga races that infest cowpea in the country. Fifteen genotypes were screened under natural infestation in field as well as inoculated in pots with three samples of the parasitic weed collected in three hot spots. The test revealed Striga attack on three multiracial Striga resistant varieties: B301, IT97K-499-35 and IT98K-205-8 suggesting the presence of other races like $\mathrm{SG}_{Z}$ in the studied area, or the breakdown of the resistance to Striga race SG3 in these cowpea varieties. Also, the resistance of HTR and Suvita 2 observed respectively in field at Kollo and in pots with Magaria sample suggested the prevalence of Striga race SG1 in these sites. From these observations, the geographical distribution of Striga races needs to be clarified in Niger and the extent to which two or more races can be associated in field requires further investigations.
\end{abstract}

(C) 2017 International Formulae Group. All rights reserved.

Keywords: cowpea, Striga races, differential response, hot spots

\section{INTRODUCTION}

Cowpea (Vigna unguiculata (L.) Walp.) is one of the most important grain legumes, fodder and cover crops in the subSaharan African countries. It complements nutritionally low-protein staple cereals and tuber crops because of its high protein content. In addition to this nutritional value, cowpea is a cash crop that generates income to farmers. Also, the crop provides good fertility restoration for cropping systems in rotation with cereals. However, despite the high adaptability of cowpea to drought-prone areas, its productivity is challenged by several biotic and abiotic stresses. Striga gesnerioides is a serious constraint to cowpea production in Sub-Saharan Africa. Yield losses ranging from $83-100 \%$ due to the infestation of this parasitic plant were recorded on susceptible cowpea varieties (Omoigui et al., 2011). Striga control is very difficult because of the long viability of its seed stock in the soil. Several control strategies including cultural practices, chemical and biological methods 
and host-plant resistance have been proposed (Dube and Olivier, 2001; Boukar et al., 2004) but no single method on its own is effective in field. The most feasible and affordable control method for small scale farmers is the use of resistant varieties coupled with adequate cultural practices. At least six different Striga races have been identified in West Africa (Botanga and Timko, 2006) based on differential test. The different Striga races were categorized as follows: SG1 (Burkina Faso), SG2 (Mali), SG3 (Nigeria and Niger), SG4 and SG4z (Benin), SG5 (Cameroon). Botanga and Timko (2006) identified another race, SG6 in Senegal. Resistant cowpea varieties with specific responses to various Striga strains were also identified (Singh, 2002). B301, a landrace originating from Botswana and IT81D-849 were found to be resistant to Striga races SG1, SG2, SG3 and SG5 (Carsky et al., 2003). Several resistance mechanisms are involved in cowpea resistance to Striga. According to Botanga and Timko (2005), the race differentiation in Striga gesnerioides was largely due to host-driven selection. On the other hand, in some hotspots of the country, previously reported resistant cultivars, HTR, for instance showed symptoms of Striga infestation; suggesting either the existence of more than one race of Striga in Niger or the breakdown of this resistance ( $\mathrm{Li}$ et al., 2009). The lack of sufficient information on the different Striga races prevailing in Niger and the ability of this parasitic weed to spread need to be addressed by conducting a differential variety test in the hot spots of the country.

Field screening with Striga inoculum have been effective in assessing the response of genotypes to Striga gesnerioides. However, field screening with artificial Striga infestation may not always be feasible because of parasite dissemination risks; and it may not always be reliable because weed pressure and distribution cannot be controlled by the researcher (Haussmann et al., 2000). Pots screening is considered as an alternative method that ensures more uniform infestation by Striga inoculum. Thus, combining hotspots and pots screening could help in identifying differential responses of cowpea genotypes to Striga.

The objective of the present research was to determine if other Striga races aside from SG3 are present in Niger using differential variety test.

\section{MATERIALS AND METHODS Location}

The experiments were carried out in the field (natural infestation) at three locations: Kollo $\left(13^{\circ} 20^{\prime} \mathrm{N}, 2^{\circ} 18^{\prime} \mathrm{E}\right)$; Maradi $\left(13^{\circ} 28^{\prime} \mathrm{N}, 7^{0} 10^{\prime} \mathrm{E}\right)$ and Magaria $\left(12^{\circ} 59^{\prime} \mathrm{N}\right.$, $\left.8^{\circ} 54^{\prime} \mathrm{E}\right)$ in 2013 and 2014 in Niger. Kollo is 30 Km South-East of Niamey and received 573 $\mathrm{mm}$ in 2013 and $595.9 \mathrm{~mm}$ in 2014. Maradi is $700 \mathrm{Km}$ East of Niamey and received 591.7 $\mathrm{mm}$ in 2013 and $435.1 \mathrm{~mm}$ in 2014. Magaria is $990 \mathrm{Km}$ East of Niamey and received 509.6 $\mathrm{mm}$ in 2013 and $491.3 \mathrm{~mm}$ in 2014 (Figure 1). The three sites chosen are the hot spots of Striga gesnerioides in the country. The pots experiment (artificial infestation) was conducted at Maradi station during the same periods.

\section{Field and pot evaluations of cowpea germplasm under Striga infestation}

Fifteen genotypes were evaluated for both field and pot experiments. The genotypes used in the test included ten race specific resistant varieties (B301, IT97K-449-35, Suvita 2, IT93K-693-2, 58-57, HTR, KVx771-10G, IT99K-573-1-1, IT98K-205-8 and TN121-80), three susceptible farmers preferred varieties (IT90K-372-1-2, KVx30309-6G and TN5-78) and two other susceptible genotypes (Dan Illa and IN92E26) to SG3 (Table 1). The genotype IT93K693-2 is resistant to all the races while B301 is resistant to all the races except SG4z. The experimental set up was a randomized complete block design with three replications. The plots were composed of two rows of $3 \mathrm{~m}$ long each with a spacing of $0.80 \mathrm{~m}$ between rows, and $0.50 \mathrm{~m}$ within the rows. Three seeds were planted per hill and were thinned to one per hill, resulting in a total of 14 plants per plot. One hundred $\mathrm{kg} \mathrm{ha}^{-1}$ of Single Super Phosphate fertilizer was applied before planting cowpea. Two hoe-weedings were done before Striga emergence. 
The pesticide applied was dimethoate $\left(\mathrm{C}_{5} \mathrm{H}_{12} \mathrm{NO}_{3} \mathrm{PS}_{2}\right)$ at pre-flowering, flowering and after pod formation to control insect pests at a rate of $11 \mathrm{ha}^{-1}$.

For the pot experiments, the same genotypes were screened using a completely randomized design replicated three times. The pots were the experimental units consisting of a single cowpea genotype. Each pot had a volume of seven liters filled with $5 \mathrm{~kg}$ of a mixture of sandy soil, clay and farmyard manure at a ratio of 2:1:1, respectively. The mixture had been previously sterilized. After soil infestation with about 1000 seeds per pot of one year-old Striga gesnerioides, the pots were watered for two weeks to precondition Striga seeds in order to break their dormancy and ensure optimum germination. Striga seeds used in this experiment were collected from the three locations (Kollo, Maradi and Magaria) where field experiments were established. Three seeds of cowpea were sown per pot in three replications. The seedlings were thinned to one per pot at 2 weeks after germination. The pots were watered every two days or when necessary in order to keep them moist. Three sets of the trials were carried out, each one infested by one of the three Striga samples.

\section{Data collection and analysis}

In this test, the term resistance to Striga means that the cowpea lines did not support any emerged Striga, although the cowpea lines may stimulate germination and permit attachment of the parasite's radicles to their roots, the development of the haustorium is inhibited and there will be no visible Striga shoots. To ease the comparison between genotypes with differential responses a two class scale: absence $(\mathrm{R}-$ an indication of resistance), presence ( $\mathrm{S}-$ an indication of susceptibility) of Striga plants was used to assess the responses of cowpea cultivars. In pots, destructive sampling was carried out 9 weeks after planting. The plant-soil mass from each pot was removed and immersed into a bucket of water. After separation of the soil mass, the roots were thoroughly washed and examined for presence of necrotic hypersensitive lesions and Striga attachments. The plants that allowed attachment, normal development and emergence of Striga gesnerioides were classified as susceptible and those free of infection were considered as resistant. The numbers of emerged Striga shoots were recorded for each cowpea genotype from the field and pots. The data from field and pots experiments were subjected to analysis of variance using SAS GLM. The differences between mean values were assessed using the least significant difference (LSD) at $5 \%$ level of significance.

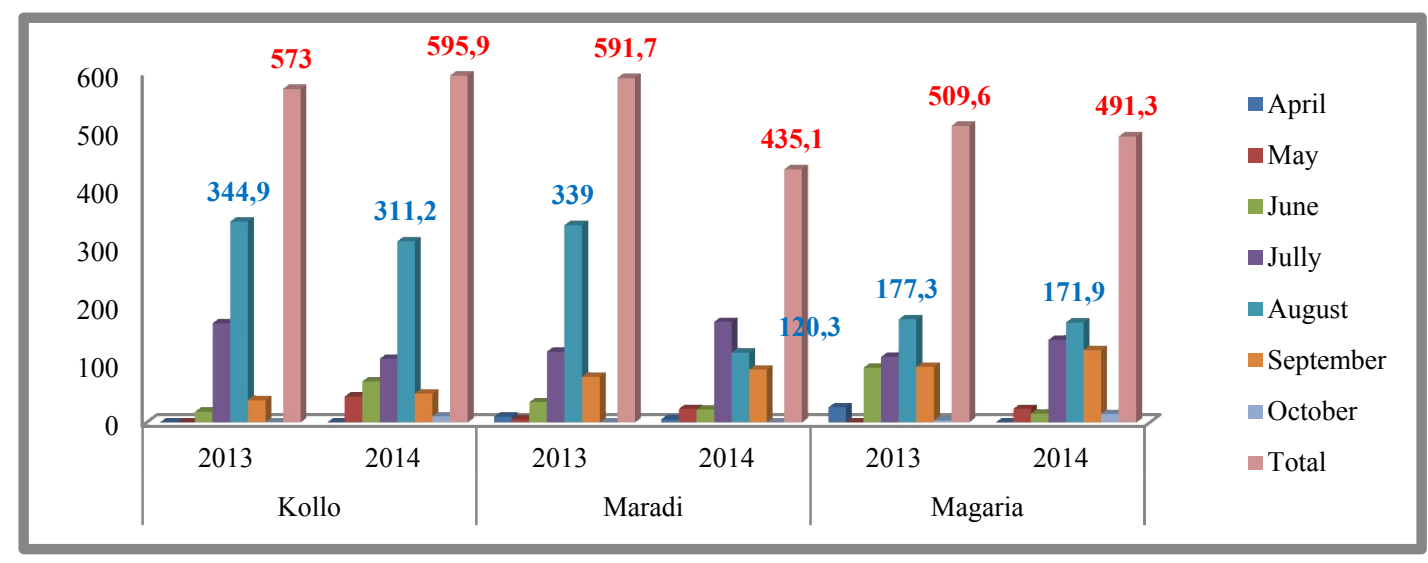

Figure 1: Mean monthly rainfall at Kollo, Maradi and Magaria in 2013 and 2014. 
Table 1: Cowpea germplasm screened at Kollo, Maradi and Magaria in 2013 and 2014 with reported differential responses to Striga races.

\begin{tabular}{llccccccc}
\hline \multicolumn{7}{c}{ Race of Striga gesnerioides, country of origin } \\
\hline $\mathbf{N}^{\mathbf{0}}$ & Cowpea cultivar & $\begin{array}{c}\text { SG1 } \\
\text { B. Faso }\end{array}$ & $\begin{array}{c}\text { SG2 } \\
\text { Mali }\end{array}$ & $\begin{array}{c}\text { SG3 } \\
\text { Niger }\end{array}$ & $\begin{array}{c}\text { SG4 } \\
\text { Benin }\end{array}$ & $\begin{array}{c}\text { SG4z } \\
\text { Zakpota }\end{array}$ & $\begin{array}{c}\text { SG5 } \\
\text { Cameroon }\end{array}$ & $\begin{array}{c}\text { SG6 } \\
\text { Senegal }\end{array}$ \\
\hline 1 & B301 & R & R & R & R & S & R & R \\
2 & IT97K-449-35 & R & R & R & S & S & S & S \\
3 & Suvita 2 & R & R & S & R & R & S & R \\
4 & IT93K-693-2 & R & R & R & R & R & R & R \\
5 & 58-57 & R & S & S & R & R & R & S \\
6 & HTR & R & S & S & S & S & S & S \\
7 & KVx771-10 G & R & S & S & S & S & R & S \\
8 & Dan Illa & S & S & S & S & S & S & S \\
9 & TN5-78 & S & S & S & S & S & S & S \\
10 & KVx30-309-6G & S & S & S & S & S & S & S \\
11 & IT90K-372-1-2 & S & S & S & S & S & S & S \\
12 & IT99K-573-1-1 & S & S & R & S & S & R & S \\
13 & IT98K-205-8 & R & S & R & S & S & R & S \\
14 & TN121-80 & S & S & R & S & S & S & S \\
15 & IN92E-26 & S & S & S & S & S & S & S \\
\hline \multicolumn{7}{l}{ Source: (Lane et al., 1996; Li et al., 2009; Omoigui et al., 2012), B. Faso: Burkina Faso } & &
\end{tabular}

Source: (Lane et al., 1996; Li et al., 2009; Omoigui et al., 2012), B. Faso: Burkina Faso

\section{RESULTS}

\section{Field experiment}

The analysis of variance for location, year and varietal effect were significant for emerged Striga shoots (Table 2). The number of emerged Striga shoots and details of cowpea responses as influenced by location and year are presented in Table 3. The differential responses of the genotypes in the three locations are presented in Table 4. Only the genotype IT93K-693-2 was completely free of emerged Striga shoots in all locations and years thus, it was completely resistant across the three locations. The varieties IT99K-573-1-1, IT97K-499-35, B301, IT98K205-8 and TN121-80 are the resistant checks to the race SG3 present in Niger that supported Striga shoots in at least two sites. B301 was infested in all sites in 2013 (Figure 2) and in 2 sites in 2014 (Table 3). All the susceptible checks to the race SG3 supported Striga shoots in the three sites, except HTR that was free of Striga emerged shoots at Kollo in 2014. The rainfall pattern of the period of the experiments is shown in Figure 1. Striga infestation was higher in 2013 than in 2014 for each site. Magaria was the site with the highest number of Striga emerged shoots while Kollo was the site with the lowest number of parasite emergence for the two years. The genotype IT93K-693-2 was free of Striga infestation across all the sites and locations. The multiracial resistant variety B301 supported emerged Striga shoots at all 
locations and years except at Maradi in year 2014. The genotype IT97K-499-35 showed Striga infestation at all locations and years except at Kollo in 2013. The line IT99K-5731-1 was infested by Striga emerged shoots at Maradi and Magaria in year 2013 while IT98K-205-8 supported emerged Striga shoots at Kollo and Magaria in 2014 and at Maradi in 2013. The variety TN121-80 showed Striga infestation at Maradi and Magaria in the two years while it was free of infection at Kollo. The genotype HTR showed no Striga emerged shoots at Kollo in 2014. All the other genotypes supported high numbers of Striga emerged shoots in all locations and years.

\section{Pot experiment}

Table 4 shows the differential responses of cowpea genotypes to $S$. gesnerioides in pots. The resistant varieties
B301, IT93K-693-2 and IT99K-573-1-1 were completely free of Striga shoots in the two years, while IT97K-499-35 (3 and 1 shoot) and IT98K-205-8 (4.33 shoots) supported significantly high numbers of Striga emerged shoots in 2014. The variety IT97K-499-35 was infested with Kollo and Maradi sample while the variety IT98K-205-8 was attacked by Magaria sample. HTR and Suvita 2 were free of Striga with Magaria sample in 2014. TN5-78 was the only susceptible variety that was free of Striga emergence at all sites in 2014. The genotypes 58-57 and TN5-78 (Figure 3) had the highest numbers of emerged Striga shoots. Striga infestation was higher in the two years in the pots infested with Striga from Kollo than those infested with Striga from Maradi and Magaria.

Table 2: Mean squares of Striga emerged shoots/plot of 15 cowpea varieties screened at Kollo, Maradi and Magaria in 2013 and 2014.

\begin{tabular}{lcccc}
\hline Source & DF & Mean Square & F Value & Pr $>$ F \\
\hline Year & 1 & 21422.31481 & 136.50 & $<.0001$ \\
Location/year & 6 & 5648.34938 & 107.97 & $<.0001$ \\
Rep/location/year & 12 & 168.52654 & 6.44 & 0.0020 \\
Entry & 14 & 2608.54656 & 16.62 & $<.0001$ \\
Year*Location & 2 & 4123.02593 & 26.27 & $<.0001$ \\
Location*Entry & 28 & 887.98862 & 5.66 & $<.0001$ \\
Year*Location*Rep & 10 & 352.03481 & 2.24 & 0.0176 \\
Year*Location*Entry & 42 & 510.27302 & 3.25 & $<.0001$ \\
\hline
\end{tabular}


Table 3: Mean numbers of emerged $S$. gesnerioides shoots per plot on 15 cowpea cultivars infested in field at Kollo, Maradi and Magaria in 2013 and 2014.

\begin{tabular}{lcccccc}
\hline & \multicolumn{7}{c}{ Striga samples } \\
\cline { 2 - 7 } & \multicolumn{2}{c}{ Kollo } & \multicolumn{2}{c}{ Maradi } & \multicolumn{2}{c}{ Magaria } \\
\hline Differential cultivars & $\mathbf{2 0 1 3}$ & $\mathbf{2 0 1 4}$ & $\mathbf{2 0 1 3}$ & $\mathbf{2 0 1 4}$ & $\mathbf{2 0 1 3}$ & $\mathbf{2 0 1 4}$ \\
\hline B301 & 2.00 & 0.33 & 10.00 & 0.00 & 57.00 & 2.67 \\
IT97K-499-35 & 0.00 & 0.67 & 1.33 & 0.33 & 0.33 & 2.33 \\
Suvita 2 & 4.67 & 1.00 & 49.33 & 5.00 & 111.00 & 21.67 \\
IT93K-693-2 & 0.00 & 0.00 & 0.00 & 0.00 & 0.00 & 0.00 \\
58-57 & 7.00 & 4.33 & 66.33 & 4.67 & 50.00 & 26.33 \\
HTR & 2.00 & 0.00 & 47.67 & 3.33 & 55.00 & 12.67 \\
KVx771-10G & 8.67 & 4.33 & 38.00 & 3.33 & 69.00 & 35.67 \\
Dan Illa & 5.33 & 2.33 & 15.20 & 5.00 & 99.67 & 50.00 \\
TN5-78 & 7.00 & 4.00 & 54.50 & 6.67 & 71.67 & 35.67 \\
KVx30-309-6G & 5.33 & 2.33 & 40.67 & 5.67 & 38.00 & 24.00 \\
IT90K-372-1-2 & 9.00 & 1.00 & 68.33 & 5.67 & 66.33 & 28.33 \\
IT99K-573-1-1 & 0.00 & 0.00 & 2.00 & 0.00 & 0.33 & 0.00 \\
IT98K-205-8 & 0.00 & 0.33 & 2.00 & 0.00 & 0.00 & 3.00 \\
TN121-80 & 0.00 & 0.00 & 33.67 & 1.33 & 5.00 & 14.33 \\
IN92E-26 & 1.00 & 0.67 & 26.33 & 2.67 & 28.00 & 22.67 \\
\hline LSD ( ps 0.05 ) & $\mathbf{4 . 7 5}$ & $\mathbf{3 . 9 0}$ & $\mathbf{2 7 . 2 4}$ & $\mathbf{4 . 4 0}$ & $\mathbf{4 0 . 6 6}$ & $\mathbf{2 8 . 1 1}$ \\
\hline
\end{tabular}

Table 4: Mean numbers of emerged $S$. gesnerioides shoots per plot on 15 cowpea cultivars infested in pots with samples from Kollo, Maradi and Magaria in 2013 and 2014.

\begin{tabular}{|c|c|c|c|c|c|c|}
\hline \multirow[b]{3}{*}{ Differential cultivars } & \multicolumn{6}{|c|}{ Striga samples } \\
\hline & \multicolumn{2}{|c|}{ Kollo } & \multicolumn{2}{|c|}{ Maradi } & \multicolumn{2}{|c|}{ Magaria } \\
\hline & 2013 & 2014 & 2013 & 2014 & 2013 & 2014 \\
\hline B301 & 0.00 & 0.00 & 0.00 & 0.00 & 0.00 & 0.00 \\
\hline IT97K-499-35 & 0.00 & 3.00 & 0.00 & 1.00 & 0.00 & 0.00 \\
\hline Suvita 2 & 1.33 & 2.33 & 2.33 & 0.67 & 1.00 & 0.00 \\
\hline IT93K-693-2 & 0.00 & 0.00 & 0.00 & 0.00 & 0.00 & 0.00 \\
\hline $58-57$ & 0.00 & 7.00 & 0.33 & 3.00 & 1.33 & 1.67 \\
\hline HTR & 3.00 & 2.67 & 1.66 & 1.33 & 0.00 & 0.00 \\
\hline $\mathrm{KVx} 771-10 \mathrm{G}$ & 1.00 & 7.00 & 0.33 & 3.00 & 0.33 & 1.33 \\
\hline Dan Illa & 5.00 & 0.00 & 2.33 & 1.00 & 0.00 & 0.33 \\
\hline TN5-78 & 6.67 & 0.00 & 1.33 & 0.00 & 0.00 & 0.00 \\
\hline KVx30-309-6G & 1.33 & 1.67 & 0.00 & 1.33 & 0.00 & 0.67 \\
\hline IT90K-372-1-2 & 3.50 & 5.00 & 1.33 & 2.33 & 0.00 & 1.00 \\
\hline IT99K-573-1-1 & 0.00 & 0.00 & 0.00 & 0.00 & 0.00 & 0.00 \\
\hline IT98K-205-8 & 0.00 & 0.00 & 0.00 & 0.00 & 0.00 & 4.33 \\
\hline TN121-80 & 1.00 & 0.00 & 2.33 & 0.00 & 1.33 & 0.00 \\
\hline IN92E-26 & 1.00 & 0.00 & 0.66 & 1.00 & 3.50 & 0.00 \\
\hline $\operatorname{LSD}(p \leq 0.05)$ & 5.79 & 5.80 & 1.79 & 3.66 & 1.96 & 3.56 \\
\hline
\end{tabular}



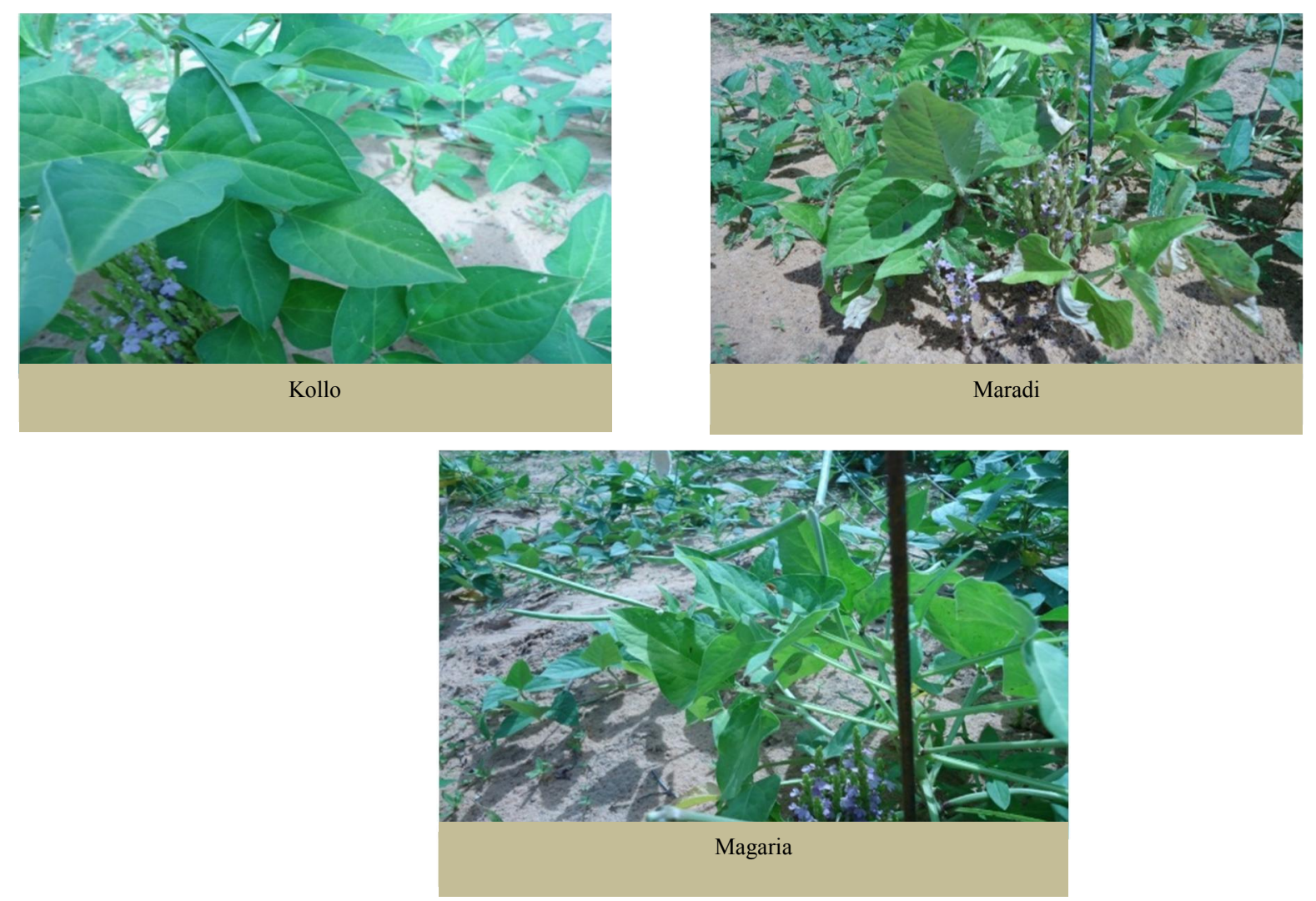

Figure 2: Infested B301 plants in field at Kollo, Maradi and Magaria in 2013.

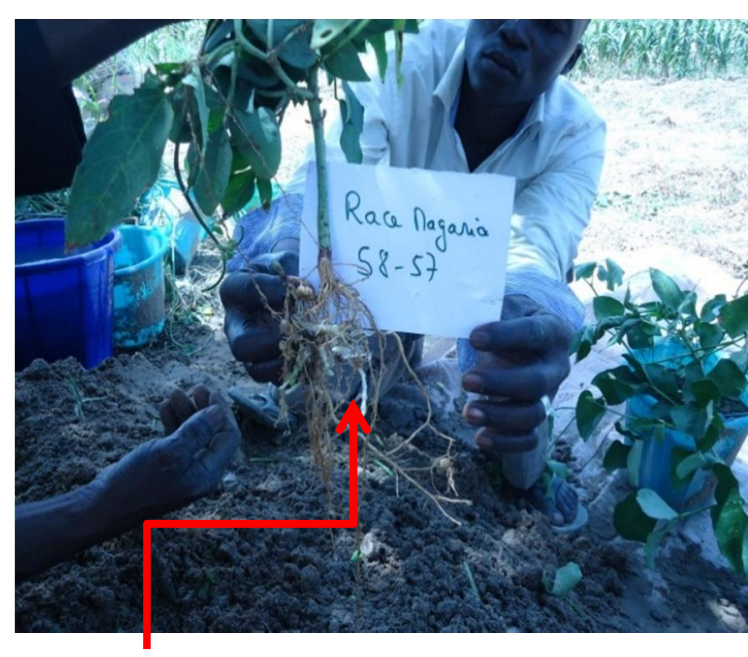

Striga attaches

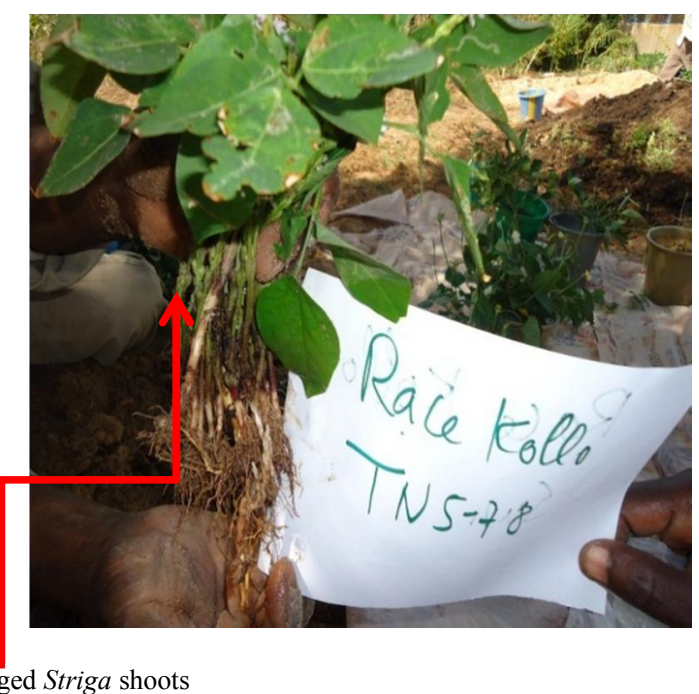

Figure 1: Susceptible varieties infested in pots. 


\section{DISCUSSION}

Three hot-spots of Striga gesnerioides in Niger were characterized using differential reactions of cowpea cultivars that were previously identified as having race specific resistance. Under natural infestation, the number of emerged Striga shoots was more across locations in 2013 compared with 2014 where emerged Striga shoots were decreased for most of the genotypes. This may be due to the rainfall amount that was higher in 2013 for most locations particularly in August, the period that coincided with Striga emergence. Magaria had the highest infestation rate probably because the soils are less fertile in this station compared with the two other sites.

In pot experiments, Striga infestation was low. The numbers of Striga emerged shoots were higher with Kollo samples and in year 2014 for all the sites. This could be attributed to the quality of Kollo inoculum in one side and the moderate amount of rainfall in 2014 at Maradi station where pot experiment was laid out in ambient temperature. Indeed, in 2013 the high amount of rainfall recorded at Maradi station compared with that of 2014 might have affected Striga emergence in pots for all the samples.

Out of the six genotypes previously reported as resistant to the race SG3, only IT93K-693-2 was completely free of Striga infestation across sites and years. The resistance observed in IT93K-693-2 confirmed the findings of Singh (2002); Boukar et al. (2004) and Tignegre (2010) who reported that this genotype was resistant to all known Striga races in Africa. IT99K-573-1-1, another resistant genotype to SG3 supported few Striga shoots in 2013 at Maradi and Magaria. This is not in line with the findings of Tchiagam et al. (2010) who observed no Striga emergence on IT99K-573-1-1 when it was screened to race SG5 in Cameroon. The multi-race Striga resistant B301 showed severe Striga infestation in the field at all sites in 2013 and at Kollo and Magaria in 2014, but it supported no Striga emergence in pots. Previously, Touré et al. (1998) found similar results with Cinzana race in Mali. Although, B301 was considered as a stable resistant genotype across four Striga races in SubSaharan Africa, these results suggest that Zakpota race $\mathrm{SG}_{Z}$ or its variants exist within S. gesnerioides populations in the study area. The resistance of B301 observed at Maradi in 2014 could be partly attributed to the rainfall pattern which was low that year compared with the previous year during which B301 showed Striga infestation at the same site. The resistance of B301 observed in pots might be due to the quality of inoculum or the presence of Striga race SG3 seeds to which B301 is resistant in the different collected samples. Another cultivar, IT97K-499-35, reported previously as resistant to Striga races 1, 2 and 3 (Singh, 2006) showed Striga emergence at all sites in the field during the two years except in 2013 at Kollo as well as with Kollo and Maradi samples in pots in 2014. This result revealed that IT97K-499-35 may not be completely resistant to race SG3 confirming early reports by Kamara et al. (2008) and Omoigui et al. (2011) suggesting the presence of new Striga races or variants in the different sites. However, further studies would be required to confirm this hypothesis.

The variety IT98K-205-8 which was previously reported to be resistant to races SG1, SG3 and SG5 showed Striga infestation in the field at Maradi in 2013 and at Kollo and Magaria in 2014 as well as with Magaria sample in pots in 2014. This result is not in line with the findings of Ajeigbe et al. (2008) who observed during two years of field evaluation under natural infestation that IT98K-205-8 and four other cultivars were completely resistant to Striga thus supported no Striga emergence in northern Nigeria where $S$. gesnerioides race SG3 is widely 
distributed. The relatively high numbers of emerged Striga shoots recorded in the field (3.33) and in pots (4.33) at Magaria suggests the breakdown of the resistance in IT98K205-8 or the presence of another $S$. gesnerioides race.

TN121-80 is another Striga race SG3 resistant cultivar that supported Striga emerged shoots in the field at Maradi and Magaria in the two years and with all the samples in pot in 2013 suggesting the breakdown of its resistance to this race or the prevalence of new races in the two localities. In the present study, all the susceptible checks to Striga race SG3 showed infestation at all sites in the field during 2013 and 2014 except the cultivar HTR that showed no Striga infestation at Kollo in 2014. This may be due to the presence of Striga race SG1 seeds for which HTR is resistant or to the escapism of this genotype from race SG3 attack, therefore corroborating previous reports (Moutari and Adam, unpublished data) who observed resistance of HTR in Western Niger and high susceptibility in East, especially at Magaria. The Striga emergence observed with Kollo sample in pots on HTR in 2013 and 2014 may be due to the mixture of the seeds from the two races together in the same field where the sample was collected. But further investigations need to be conducted to confirm this hypothesis.

Five Striga susceptible cultivars that showed infestation in field supported no emerged Striga shoots in pots in 2014. These cultivars include HTR and Suvita 2 for Magaria sample, Dan Illa for Kollo, TN5-78 for samples from all sites and IN92E-26 for Kollo and Magaria samples.

The differences observed between field and pots results for some cultivars could be partly attributed to the artificial and highly limited root environment in pots and other factors like humidity or inoculum quality that may affect Striga emergence. HTR and Suvita 2 are recognized resistant cultivars to Striga race SG1; therefore Magaria sample used as inoculum in pots experiment may contain Striga race SG1 seeds or that the conditions required for a good Striga emergence were not fulfilled. Assuming that most of the results from pots that were not concordant with field observed susceptibility were escape. The combined results of differential responses revealed the following status of the three hotspots about $S$. gesnerioides race distribution:

At Kollo, Striga emergence observed on cowpea genotypes B301, IT97K-499-35 and IT98K-205-8 would have confirmed the prevalence of Striga race $\mathrm{SG} 4 \mathrm{z}$ if only the varieties Suvita 2 and 58-57 were not susceptible. Indeed these varieties were reported to be resistant to race SG4 (Lane and Bailey, 1992). This suggests the presence of Striga race SG3 with $\mathrm{SG} 4 \mathrm{z}$ or its variant. Also, the resistance of HTR observed could be explained by the prevalence of race SG1 with SG3 in the same field. This hypothesis of compendium, that is the mixture of more than one Striga race seeds in the same field requires further investigations.

At Maradi, the resistance of cowpea varieties B301 and IT98K-205-8 observed in 2014 coupled with the susceptibility of Suvita-2, 58-57 and HTR may be justified by the presence of Striga SG3. However, Striga infestation on IT97K-499-35 and TN121-80 in the two years may be due to the breakdown of SG3 resistance or the presence of a new race.

At Magaria, Striga attack observed on cowpea varieties B301, IT97K-499-35 and IT98K-205-8 coupled with the resistance of Suvita-2 observed in pots may be due to the presence of Striga race SG4z. The emergence of Striga on 58-57 and Suvita-2 in field suggests the prevalence of Striga race SG3. The presence of Striga race SG1 with the other two races was probably indicated by the resistance of cowpea variety HTR observed in pots in both years. 


\section{Conclusion}

This study confirmed the potential of some cowpea cultivars to control Striga gesnerioides and revealed race specificity and ability of this parasitic weed to overcome recognized resistance. The breeding line IT93K-693-2 is a potential parent for use in transferring Striga resistance into adapted and farmer preferred varieties. The varieties B301, IT97K-499-35, IT99-573-1-1 and IT98K-2058 were found not completely resistant, thus indicating either the breakdown of their resistance to Striga race $\mathrm{SG} 3$ or the prevalence of Striga race $\mathrm{SG} 4 \mathrm{z}$ or variants in Niger particularly at Magaria and Kollo. Also, the resistance of HTR and Suvita-2 in the two localities would not exclude the prevalence of Striga race SG1. The use of sophisticated screening techniques such as molecular studies of a representative collection of Striga samples throughout the country would be needed to ascertain the geographical distribution of Striga races in Niger. Breeding for multi-racial Striga resistant cowpea varieties by gene pyramiding or transferring a gene that confers the resistance to all known Striga races in the locally adapted cultivars is required urgently.

\section{COMPETING INTERESTS}

The authors declare they have no competing interests.

\section{AUTHORS' CONTRIBUTIONS}

MS and JBLST conceived and designed the experiments. MS performed the experiments, analyzed the data and wrote the manuscript. JBLST, PT, SO, KO, ED reviewed the manuscript.

\section{ACKNOWLEDGEMENTS}

The authors would like to acknowledge AGRA for its entire financial support to this project research.

\section{REFERENCES}

Ajeigbe H, Ihedioha D, Chikoye D. 2008. Variation in physico-chemical properties of seed of selected improved varieties of cowpea as it relates to industrial utilization of the crop. Afr. J. Biotechnol., $7(20)$ : 3642-3647. https://www.ajol.info/index.php/ajb/articl e/viewFile/59398/47695.

Botanga CJ, Timko MP. 2005. Genetic structure and analysis of host and nonhost interactions of Striga gesnerioides (witchweed) from central Florida. Phytopathology, 95: 1166-1173. http://apsjournals.apsnet.org/doi/pdf/10.1 094/PHYTO-95-1166

Botanga CJ, Timko MP. 2006. Phenetic relationships among different races of Striga gesnerioides (Willd.) Vatke from West Africa. Genome, 49: 1351-1365.

Boukar O, Kong L, Singh B, Murdock L, Ohm H. 2004a. AFLP and AFLPDerived SCAR Markers Associated with Resistance in Cowpea. Crop Science, 44: 1259-1264.

Boukar O, Kong L, Singh BB, Murdock L Ohm HW. 2004b. AFLP and AFLPderived SCAR markers associated with Striga gesnerioides resistance in cowpea. Crop Science, 44: 1259-1264.

Dube MP, Olivier A. 2001. Striga gesnerioides and its hosts, the cowpea: Interaction and methods of control. Canadian Journal of Botany-Revue Canadienne de Botanique, 79: 12251240.

Haussmann BI, Hess DE, Welz HG, Geiger HH. 2000. Improved methodologies for breeding Striga-resistant sorghums. Field Crops Research, 66: 195-211.

Kamara AY, Chikoye D, Ekeleme F, Omoigui LO, Dugje IY. 2008. Field performance of improved cowpea varieties under conditions of natural infestation by the parasitic weed Striga gesnerioides. International Journal of Pest Management, 54: 189-195. http://www.tandfonline.com/doi/abs/10.1 080/09670870801930260

Li J, Lis KE, Timko MP. 2009. Molecular genetics of race-specific resistance of cowpea to Striga gesnerioides (Willd.). 
Pest Management Science, 65: 520-527. http://onlinelibrary.wiley.com/doi/10.100 2/ps.1722/full

Omoigui L, Kamara A, Ishiyaku M, Boukar, O. 2011. Comparative responses of cowpea breeding lines to Striga and Alectra in the dry savanna of northeast Nigeria. African Journal of Agricultural Research, 7:

747-754. http://www.academicjournals.org/journal /AJAR/article-full-textpdf/A813A9A37696

Singh B. 2006. Cowpea breeding at IITA: Highlights of advances impacts. In: Anais do congresso nacional de feijãocaupi. Embrapa Meio-Norte, Teresina, p. $1-4$.

Singh BB. 2002. Breeding cowpea varieties for resistance to Striga gesnerioides and Alectra vogelii. Challenges and Opportunities for Enhancing Sustainable Cowpea Production, 154-163.

Tchiagam JBN, Bell JM, Birwe SG, Gonne S,
Youmbi E. 2010. Varietal response of cowpea (Vigna unguiculata (L.) Walp.) to Striga gesnerioides (Willd.) Vatke race SG5 infestation. Notulae Botanicae Horti Agrobotanici Cluj-Napoca, 38: 3341. http://www.notulaebotanicae.ro/ index. $\mathrm{php} / \mathrm{nbha} /$ article/viewFile/4856/ 4508

Tignegre JBDLS. 2010. Genetic study of cowpea (Vigna unguiculata (L.) Walp) resistance to Striga gesnerioides (Willd.) vatke in Burkina Faso. Ph.D thesis. School of agricultural sciences and agribusiness. University of KwazuluNatal, South Africa, 167 p.

Touré M, Olivier A, Ntare BR, Lane JA, StPierre CA. 1998. Reaction of cowpea (Vigna unguiculata) cultivars to Striga gesnerioides races from Mali and Niger. Canadian Journal of Plant Science, 78: 477-480. http://www.nrcresearchpress. com/doi/pdf/10.4141/P97-123. 